\title{
Bovine Herpesvirus 1 (BoHV-1) in Cattle and Buffalo: A Review with Emphasis on Seroprevalence in India
}

\author{
Sheza Farooq, Aman Kumar*, Suman Chaudhary and Sushila Maan \\ Department of Animal Biotechnology, LUVAS, Hisar, India \\ *Corresponding author
}

Keywords

BoHV-1,

Seroprevalence, ELISA, Serum, etc.

Article Info

Accepted:

04 November 2019

Available Online:

10 December 2019

\section{A B S T R A C T}

Bovine herpesvirus-1 (BoHV-1) mainly causes two forms of diseases in cattle and buffalo that is Infectious bovine rhinotracheitis (IBR) and Infectious pustular vulvovaginitis (IPV). These infections occur worldwide however, in India first time reported in 1976. Since than several studies have been conducted in different part of the country to know the seroprevalence. This review focused on updated information on the emergence and seroprevalence of BoHV-1 in India.

\section{Introduction}

BoHV-1 is classified under family Herpesviridae, subfamily Alphaherpesvirinae and genus Varicellovirus. There are different subtypes of virus are known: BoHV1.1 and $1.2 \mathrm{a}$ (associated with infectious bovine rhinotracheitis), $1.2 \mathrm{~b}$ (associated with infectious pustular vulvovaginitis and infectious balanopothitis (IBP) (Biswas et al., 2013). BoHV-1 infection clinically characterised by rhinotracheitis, vaginitis, balanoposthitis, abortion, conjunctivitis, and enteritis. It is also associated with shipping fever, also known as bovine respiratory disease (BRD). Secondary bacterial infections may lead to pneumonia, especially in intensively managed livestock, such as beef cattle and in feedlots. The venereal forms of the disease result in pustular lesions in the prepuce and penile epithelium of the bull and vulva and vagina of the cow. Mehrotra et al., (1976), first time isolated the virus from cases of kerato conjunctivitis amongst crossbred calves at an organized cattle herd in Uttar Pradesh. Since then the disease has been reported in most of the states of India. Initially, the disease was found to be more prevalent in exotic and crossbred cattle than in indigenous breeds. In India, the disease is endemic. As BoHV-1 is excreted in semen and can be spread by artificial insemination hence bulls entering artificial breeding centres must be negative for BoHV1 infection. Several serological tests are available for the detection of antibody and a rise in titre between the 
acute and convalescent phase of infection. The primary immune response to BoHV-1 experimental inoculation of cattle is characterized by the formation of both IgM and IgG antibodies. Secondary immune responses are characterized primarily by the formation of $\operatorname{IgG} 2$ antibody. Virus (serum) neutralisation tests (VNT) and indirect or blocking (competitive) enzyme-linked immunosorbent assays (ELISAs) are commonly employed for the detection of BoHV1 antibodies in bovine serum. (Oie., 1998). The VNT has been widely used and is the gold standard by which other techniques have been evaluated (Perrin et al., 1996). However, the ELISA is a specific, sensitive, and more practical test for detection of BoHV1 antibodies. A variety of ELISAs, namely indirect ELISA, c-ELISA, and AB-ELISA have been employed to screen serum samples of cattle and buffaloes in India (Nandi et al., 2004, 2007). The IgM-ELISA is useful for the diagnosis of recent infection with BoHV-1 in calves (Ungar-Waron and Abraham, 1991). Presently, BoHV-1 gE blocking ELISA (Wellenberg et al., 2001) is the only available assay that differentiates antibodies against BoHV-1 from BHV-5. All seropositive cattle except for calves that have ingested colostrum containing BoHV1 antibodies are considered to be carriers of BoHV1. A rise in antibody titre indicates an acute infection or reactivation of virus from a latent infection (Oie, 1998).

\section{Pathogenesis}

Virus enters through aerosol route or by direct contact with the nasal secretion in case of respiratory tract infection and by direct contact or by semen containing virus (coitus or AI) in case of genital infection. Within animal body, BoHV-1 is transported by monocytes and white blood cells to target organs. During primary infection of the respiratory tract, BoHV-1 replicates in the nasal and ocular epithelia, which then leads to development of fever within 2-3 days post exposure with subsequent increase in respiratory rate and inappetance and also decrease in milk yield is seen in case of dairy cattle. Areas of focal necrosis are evident, often leading to serious nasal/ocular discharge and conjunctivitis. In both genital and respiratory form of disease there is a focal area of epithelial cell necrosis, in which there is ballooning of epithelial cells. Typical herpesvirus inclusions may be present in nucleus of periphery of necrotic foci. There is intense inflammatory response within the inflamed mucosa frequent with formation of overlaying accumulation of fibrin or cellular debris (pseudomembrane). Liver and adrenal are affected most. It may lead to secondary bacterial infection contributing to the complex syndrome called shipping fever (Bovine respiratory disease complex) and culminates in severe pneumonia caused by Mannheimia haemolytica (Majumder et al., 2015). The pathogenesis cycle of BoHV-1 is described in figure 1.

\section{Sero-prevalence in India}

IBR is considered as endemic diseases of cattle in India. The disease was found to be more prevalent in exotic and crossbred cattle than in indigenous breeds. In Gujarat, Patel (1983) reported that 24 out of 32 paired sera of aborted buffaloes were positive for IBR antibodies. Suri Babu et al., (1984) screened serum samples for BoHV-1 antibodies by indirect Haemagglutination test and reported a seroprevalence of $64.72 \%$ in the states of Andhra Pradesh, Karnataka, Orissa, Tamil Nadu and West Bengal. Mallick (1986) studied the seroprevalence of IBR disease in seven states and observed that $65.3 \%$ exotic, $73 \%$ crossbred and $62 \%$ indigenous cattle were seropositive. Further, several seroprevalence studies have been carried out by different researchers and it was seen that the disease is prevalent in almost all the states 
of India. Satyanarayana and Suri Babu (1987) using indirect Haemagglutination test, reported 56.5 \% BoHV-1 seroprevalence in the states of Uttar Pradesh, Haryana, West Bengal, Orissa, Andhra Pradesh, Tamil Nadu and Karnataka. Renukaradhya et al., (1996) found that $50.9 \%$ cattle and $52.5 \%$ buffalo population in the states of Andhra Pradesh, Karnataka and Tamil Nadu are seropositive for BoHV-1 antibodies. Vaid et al., (1991) screened 76 samples of cattle of Himachal Pradesh for the presence of BoHV1 antibodies and $49(64.47 \%)$ were found sero-positive by passive Haemagglutination test. Suresh and team (1992) reported overall sero-positivity of $33.97 \%$ in Tamil Nadu after screening of 156 sera samples of buffaloes by passive HA.

Pandita and Srivastava (1995) studied the efficacy of dot ELISA and plate ELISA with 239 bovine serum samples from Haryana against IBR antibody and 51.9 and $48.5 \%$ were found positive by plate ELISA and dot ELISA respectively. Shome with team (1997) recorded prevalence of BoHV-1 in Andaman and Nicobar Islands with the help of A-B ELISA. A total of 203 serum samples were processed and about $89 \%$ of cattle showed presence of BoHV-1 antibodies. Tripathi et al., (1998) reported involvement of BoHV-1 in causing repeat breeding cases. Out of 75 total repeat breeders, $55(73.3 \%)$ cattle were found positive for IBR.

Suresh et al., (1999) standardised Avidin Biotin ELISA for detection of BoHV-1 antibodies in serum samples. They conducted the first large scale seroprevalence of BoHV-1 in India covering eighteen states and union territories. They reported $38.01 \%$ of cattle in India are seropostive for BoHV-1 antibodies. The state wise BoHV-1 seroprevalence what they recorded is as follows: $96.55 \%$ in Andaman and Nicobar; $37.56 \%$ in Andra Pradesh; $69.05 \%$ in Arunachal Pradesh; 13.64 $\%$ in Assam; $76.74 \%$ in Bihar; $42.50 \%$ in
Goa; $10 \%$ in Gujarat; 9.095 in Haryana; 12.82 $\%$ in Himachal Pradesh; $95.35 \%$ in Jammu and Kashmir;64.22 \% in Karnataka; $46.67 \%$ in Madya Pradesh; $77.90 \%$ in Maharashtra; $51.11 \%$ in Manipur; $13.64 \%$ in Mizoram; $100 \%$ in Orissa; $23.66 \%$ in Punjab; $60.16 \%$ in Rajastan; $20.16 \%$ in Tamil Nadu and $82 \%$ in the state of Uttar Pradesh.

Dhand et al., (2002) screened 202 serum samples of cattle and 337 of buffaloes of Punjab against IBR virus using A-B ELISA and found overall $28.76 \%$ seropositivity and $34.16, \quad 17.48 \%$ sero-positivity in cattle buffaloes respectively. Rajesh et al., (2003) studied the sero-prevalence of IBR in cattle population of Kerala. Out of 719 serum samples tested, 107 samples $(14.88 \%)$ showed positive reaction by AB-ELISA in Kerala. Singh et al., (2004) found $11.82 \%$ overall prevalence for IBR in organized dairy farms of Punjab. Deka et al., (2005) observed $45.09 \%$ sero-positivity in breeding bulls and detected presence of virus in semen by isolation and PCR methods. Jain et al., (2006) collected 231 bovine serum samples from Garwal district of Uttaranchal State and reported $10.39 \%$ overall sero-prevalence of IBR by A-B ELISA. In cattle, it was $10.75 \%$ out of 186 and $8.89 \%$ in buffaloes out of 45 in total. Sharma et al., (2006) examined 80 serum samples by AB ELISA for IBR among cattle in Himachal Pradesh and found 40 samples positive. Koppad with team (2007) screened 500 cattle serum samples collected from organized farm and rural sector of Karnataka and reported $19.2 \%$ overall prevalence of BoHV-1.

Nandi and team (2007) collected 189 serum samples from cattle (34 male and 155 female) from an organized farm at Bharari, Jhansi; were tested by indirect ELISA and 38 male and $66 \%$ female serum samples were found positive with an overall $61 \%$ positivity to antibodies to BHV-1. Singh and Yadav (2010) 
studied sero-prevalence of BoHV-1 in Uttar Pradesh. A total of 312 blood samples of cattle (of 1-4 years age) from various farms and gaushalas and 180 blood samples of cattle from unorganized herds were collected and analysed. Out of the 492 samples, 159 samples were found positive for anti BoHV-1 antibodies with an overall prevalence of $32.31 \%$.They also reported higher seroprevalence of BoHV-1 at organized herds $(43.3 \%)$ as compared to unorganized herds (13.2\%).

Verma et al., (2014) performed cross-sectional study to detect the seroprevalence of infectious bovine rhinotracheitis in dairy animals of Uttar Pradesh, India using commercial ELISA kit (SYANOVIR® IBR$\mathrm{Ab})$ to know anti BoHV-1 antibodies. Crosssectional serological studies on 134 blood samples on cattle of different age, gender from 8 districts revealed an overall individual seroprevalence of $32.84 \%$. This study also revealed higher seroprevalence in cattle $(46.51 \%)$ as compared to buffalo (35.28\%). Comparison of different sex groups of animals revealed that the higher numbers of infected animals were identified in male $(48.00 \%)$ than female $(29.35 \%)$. The seropositivity of IBR increased with age of animals. The highest prevalence of IBR $(66.67 \%)$ was observed in animals aged more than 8 years.

Chettri and co-worker (2016) studied seroprevalence of BoHV1 on 118 serum of Jersey and Holstein-Friesian (HF) crossbred cattle with various reproductive disorder belonging to different private dairy farms located in and around Guwahati, Assam by Avidin-Biotin ELISA kit. The sero prevalence of BoHV-1 among dairy cattle was found to be $20.34 \%$. Moreover, the sero prevalence was higher in HF cross bred than in Jersey cross bred animals while lower sero-prevalence was recorded in young ones as compared to older animal. They also reported the incidence of positive reactors with history of abortion, repeat breeding, retention of placenta, mastitis and in pregnant and apparently healthy animal was $43.75 \%, 36.36 \%, 16.16 \%, 11.11 \%, 7.69 \%$ and $3.03 \%$ respectively. Samrat et al., (2016) reported an overall sero-prevalence of $34.69 \%$ of BoHV-1 antibodies in Chhattisgarh. His study was based on 464 serum samples from cattle and buffaloes of different districts of the state. The collected serum samples were screened by Avidin-Biotin Enzyme Linked Immunosorbent Assay kit. The overall Seroprevalence in cattle $(37.44 \%)$ was comparatively higher than in buffales $(7.14 \%)$. Age-wise prevalence of BoHV-1 varied i.e. animal above 9 years of age showed the highest seropositivity (45.9\%) as compared to young animals of 0 to 2 years of age $(6.89 \%)$. Breed-wise, crossbred cattle showed higher seropositivity $(40.42 \%)$ followed by nondescript cattle $(39.77 \%)$ than in indigenous cattle $(22.03 \%)$. Interestingly, Murrah buffalo was found seronegative., Nagpuri and indigenous buffaloes showed seropositivity of $0 \%, 3.03 \%$ and $50 \%$, respectively. In the present study, seropositivity of $36.53 \%$ and $37.56 \%$ was recorded in male and female cattle, respectively. Male and female buffalo showed $11.11 \%$ and $6.06 \%$ seropositivity, respectively. Seropositivity of $45.45 \%$ was recorded in animals without clinical signs whereas animals with history of different clinical conditions showed $24.46 \%$ seropositivity. Out of 422 cattle serum samples, $158(37.44 \%)$ were found positive compared to $3(7.14 \%)$ serum samples out of 42 from buffaloes. In different age groups, there was variability in prevalence of BoHV1. Animals above 9 years of age showed the highest sero-positivity (45.9\%) whereas young animals between 0 to 2 years of age showed the minimum sero-positivity (6.89\%). Crossbred cattle showed higher sero-positivity $(40.42 \%)$ followed by non-descript cattle whereas indigenous cattle showed the seropositivity of $39.77 \%$ and $22.03 \%$, 
respectively. Patil et al., (2017) conducted a systematic sero-surveillance of IBR in India. They took a total of 1000 cattle serum samples from 11 dairy farms located in 4 different regions i.e. noth, south east and west of India and analysed anti BoHV-1antibodies using avidin biotin ELISA. They observed wide seroprevalent of anti BoHV-1antibodies in all regions of the country ranging from 36.5 in Central region to $84.5 \%$ in Northern region with an overall prevalence of $61.6 \%$. The details of the result are mentioned in the table 1. The prevalence of IBR antibodies was different between various age groups being $22.3 \%, 62.1 \%, 59.3 \%, 76.1 \%$ and $66.78 \%$ in the age groups less than 1 year, 1-2 years, 2-3 years, 3-4 years and more than 4 years old respectively.
Thakur et al., (2017) conducted seroprevalence study on 489 serum samples of unvaccinated bovine population of five districts i.e. Dehradun, Haridwar, Nainital, Pithoragarh, and Udham Singh Nagar of Uttrakhand using BoHV-1 antibodies specific avidin biotin enzyme-linked immunosorbent assay and observed an overall prevalence of 29.03\%. At district level, the highest prevalence was recorded in Pithoragarh district $(40.00 \%)$ and lowest in Udham Singh Nagar (16.00\%). The higher sero prevalence of BoHV-1 antibodies was found in unorganized dairy units $(31.02 \%)$ compared to organized farms $(26.51 \%)$. Buffaloes were found to have greater prevalence $(38.14 \%)$ than cattle $(26.78 \%)$ and sex-wise basis; females (30.08\%) were harbouring higher antibodies to the virus than males (16.21\%).

Fig.1 Pathogenesis route of BoHV-1

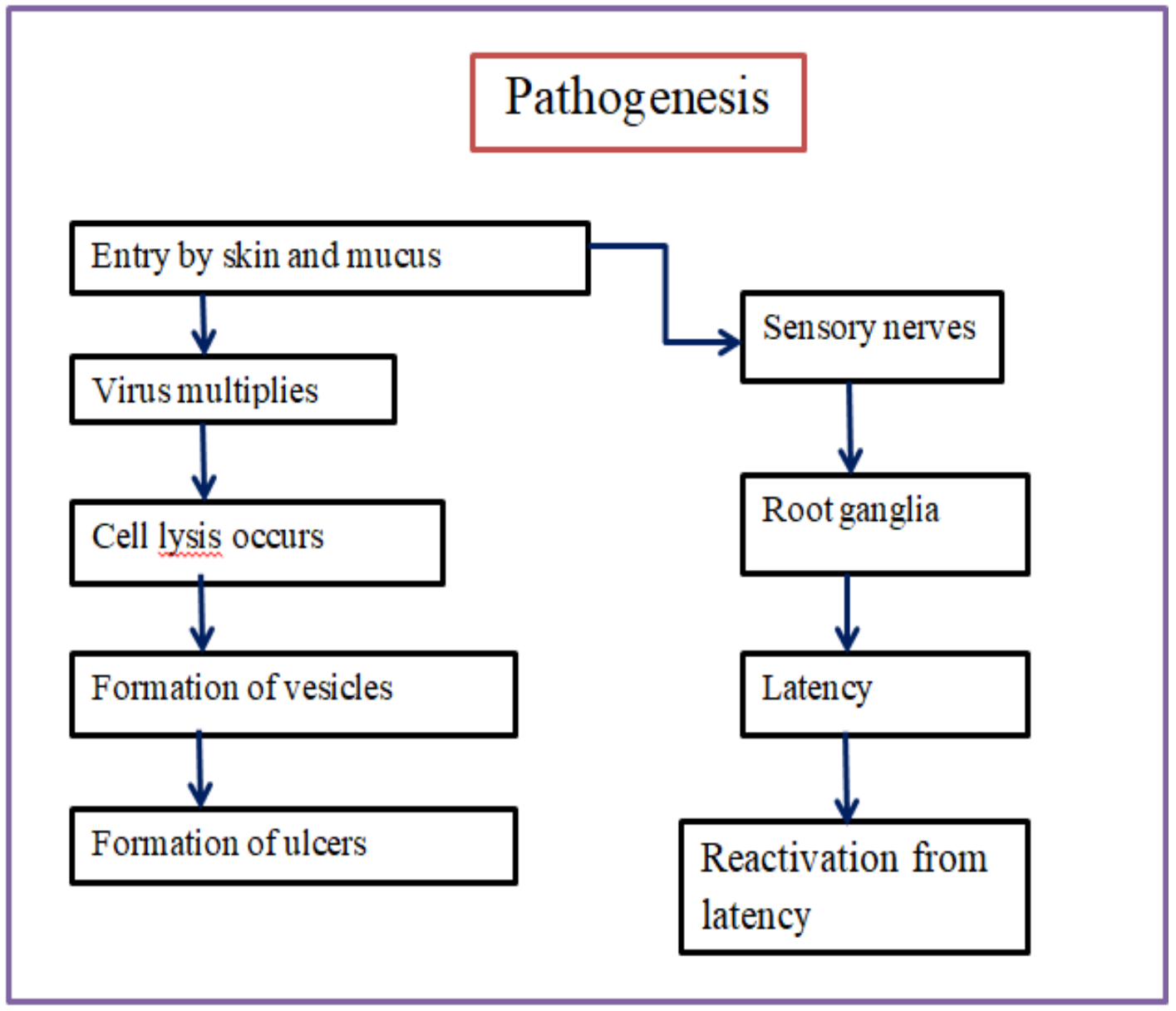


Table.1 Region and state wise sero-prevalence of IBR in cattle

\begin{tabular}{|c|c|c|c|c|c|}
\hline Region & $\begin{array}{l}\text { Farm } \\
\text { location }\end{array}$ & $\begin{array}{l}\text { Tested animals } \\
\text { (Positive } \\
\text { animals) }\end{array}$ & $\begin{array}{c}\text { Percent } \\
\text { Seroprevalence }\end{array}$ & $\begin{array}{c}\text { Percent } \\
\text { Seropositive } \\
\text { cows }\end{array}$ & $\begin{array}{c}\text { Percent } \\
\text { Seropositive } \\
\text { calves }\end{array}$ \\
\hline \multirow[t]{2}{*}{ North } & Uttarakhand & $100(85)$ & \multirow[t]{2}{*}{84.5} & 90 & 50 \\
\hline & Punjab & $100(84)$ & & 95 & 40 \\
\hline \multirow[t]{2}{*}{ Central } & $\begin{array}{l}\text { Madhya } \\
\text { Pradesh }\end{array}$ & $100(7)$ & \multirow[t]{2}{*}{36.5} & 7.7 & 0 \\
\hline & Chhattisgarh & $100(66)$ & & 72 & 10 \\
\hline West & Maharashtra & $200(153)$ & 76.5 & 82.2 & 25 \\
\hline \multirow[t]{3}{*}{ South } & $\begin{array}{l}\text { Andhra } \\
\text { Pradesh }\end{array}$ & $200(117)$ & \multirow[t]{3}{*}{55.25} & 60.6 & 15.4 \\
\hline & Tamilnadu & $100(34)$ & & 37.7 & 0 \\
\hline & Karnataka & $100(70)$ & & 75.5 & 20 \\
\hline
\end{tabular}

Kathiriya et al., (2018) studied seroprevalence of infectious bovine rhinotracheitis (BoHV-1) in dairy animals with reproductive disorders in Saurashtra of Gujarat. The study revealed that BoHV-1 is comparatively more widespread in cattle $(36.31 \%)$ than buffalo $(33.99 \%)$. He also reported that the seropositivity of IBR increased with age of animals and the highest prevalence of IBR $(42.07 \%)$ was observed in animals aged more than 7 years.

Tresamol et al., (2019) conducted crosssectional study during 2016-17, for assessing the seroprevalence of BoHV-1 among cattle and buffaloes maintained in organised and unorganised farms in Thrissur and Palakkad districts of Kerala, India. A total of 600 animals including 517 cattle and 83 buffaloes were included in the study. The sera samples from the animals were subjected to Avidin Biotin Enzyme Linked Immunosorbent Assay for detection of antibodies to BoHV-1. This study showed an overall positive reaction of $12.0 \%$. Among 517 cattle, 55 animals including 3 Vechur cows showed positive reaction (10.63\%). However, among 83 buffaloes, $17(20.48 \%)$ were positive for antibodies to BoHV-1.
On the basis of above serological data it can be concluded that BoHV-1 is circulating in almost all states of the country. The seroprevalence is higher in cattle as compared to buffalo and aged animals are more prone to infection as compared to young one. There is a need of effective control programme for control and eradication of the disease

\section{References}

Chettri S, Ahmed K, Bora DP, Dutta LJ, Bora M, Sharma DK. 2016. Reproductive Status in Bovine Herpes Virus 1 (BHV-1) sero-positive Dairy Cattle. Ind J Ani Repro. 36(2).

Deka D, Ramneek, Maiti NK, Oberoi MS. 2005. Detection of bovine herpesvirus1 infection in breeding bull semen by virus isolation and polymerase chain reaction. Rev Sci Tech OffIntEpiz, 24: 1085-1094.

Dhand NK, Singh G, Sharma DR, Sandhu KS. 2002. Seroprevalence of IBR in Punjab. Indian J AnimSci 72:850-852.

Jain V, Parihar AK, Upadhayay AK, Kumar M. 2006. Seroprevalance of IBR among bovines of Garwal region. Indian Vet J. 83: 340-342. 
Kathiriya J, Sindhi S, Mathapati B, Bhedi K. 2018. Seroprevalence of Infectious Bovine Rhinotracheitis (BHV-1) in dairy animals with reproductive disorders in Saurashtra of Gujarat, India Seroprevalence of infectious bovine rhinotracheitis (BHV-1) in dairy animals with reproductive disorders in Saura. Int J Cur Microbiol Appl Sci 7(3): 1371-6.

Koppad KK, Patil SS, Shome R, Desai GS, Bhure S, Gajendragad MR, Tiwari GB, Prabhudas K. 2007. Seroprevalence of infectious bovine rhinotracheitis in Karnataka. Ind Vet J 84(6): 569-572.

Majumder S, Ramakrishnan MA, Nandi S. 2015. Infectious Bovine Rhinotrachitis: An Indian Perspective. Int J Cur Mic App Sci4:844-858.

Mehrotra ML, Rajya BS, Kumar S. 1976. Infectious bovine rhinotracheitis (IBR) keratoconjunctivities in calves. Indian $J$ Vet Path 1:70-73.

Moussa AA, Saber MS, Nafie E, Shalaby MA, Atoub NN, Nakshaly El, Mohsen S, Madboulv AY, SanousiHMEl, Fathia AA, Sami MM, Allam AI, Reda IM. 1990. Serological survey on the prevalence of bovine herpes-1(BHV-1) in domestic animals in Egypt Vet Med J Giza 38: 87-94.

Nandi S, Kumar M, Manohar M, Chauhan RS. 2009. Bovine herpes virus infections in cattle. Anim Health Res Rev 10:85-98.

Nandi S, Pandey AB, Sharma K, Audarya SD, Chauhan RS. 2007. Seroprevalence of infectious bovine rhinotracheitis in cattle of an organized farm by indirect ELISA. The Indian cow: The Scientific and Economic Journal 4:09729585.

Pandita N, Srivastava RN. 1995. Dot immunobinding assay for detection of bovine herpes virus-1 (BHV-1) antibodies. Ind J Vir 11:27-29.

Patil SS, Prajapati A, Krishnamoorthy P, Desai GS, Reddy GBM, SureshKP,
Rahman H. 2017. Seroprevalence of Infectious bovine rhinotracheitis in organized dairy farms in India. Indian J Anim Res. 51: 151-154.

Perrin M, Dannacher G, Coudert M, Fedida M. 1981. Infectious bovine rhinotracheitis in France: results of the 1978 national survey. Recueil de med Veterinaire 157:485- 490.

Rajesh J. B, Tresamol PV, Saseendranath MR. 2003. Seroprevalence of infectious bovine rhinotracheitis in cattle population of Kerala. Indian Vet $J$ 80: 393-396.

Saha T, Guha C, Chakraborty D, Pal BP, Biswas U, Chatterjee, A, Koenig P, Beer M. 2013. Isolation and Characterization of BoHV-1 from Seropositive Cows after Inducing Artificial Stress in West Bengal, India. Pak J Biol Sci., 16:720-725.

Samal SK, Mallick BB, Das SK. 1981. Note on the incidence of IBR virus infection among cattle in India. Indian $J$ AnimSci 51:895-897.

Samrath D, Shakya S, Rawat N, Gilhare VR, Singh F, Khan FF. 2016. Seroprevalence of bovine herpes virus type 1 in cattle and buffaloes from Chhattisgarh. Jani Res 6(4): 641-644.

Satbige AS, Kuotsu K, Patil NA, Kasaralikar VR, Bijurkar RG, Sandeep H. 2018. Molecular detection of bovine herpes virus -1 (BHV-1) infection in cattle in organised and unorganised farm in Bidar, Karnataka. J Entomol Zool Stud 6(4): 1258-1260.

Sharma M, Katoch RC, Charanjeet,Dhar P. 2006. Seroprevalance of IBR among cattle in Himachal Pradesh. Indian Vet J., 83: 1-3.

Shome BR, Rajeswari S,Shrivastava N.1997. Seroprevalence of antibodies to BHV1 in cattle of Andaman. Indian Vet $J$ 74:34-736. 
Singh B. B, Sharma S, Kumar H,Dhand NK. 2004. Surveillance of diseases in organized dairy farms of Punjab. J Res, PAU 41: 490-494.

Singh M. 2014. Molecular Characterization of Indian isolates of Bovine Herpes Virus-1. M.V.Sc. thesis, submitted to LUVAS, Hisar

Singh R, Yadav S. 2010. Seroprevalence of bovine herpes virus -1 in Uttar Pradesh. Haryana Vet., 49: 54-59.

Suresh S. 1992. Seroprevalence studies of infectious bovine rhinotracheitis/ infectious pustular vulvovaginitis (IBR/IPV) infection in cattle. M.V.Sc. Thesis submitted to TNVASU, Chennai.

Thakur V, Kumar M, Rathish RL. 2017. Seroprevalence of bovine herpesvirus1 antibodies in bovines in five districts of Uttarakhand. Vet World 10(2):140.

Tongaonkar SS, Singh BK, Rama Kant. 1986. Comparative prevalence of the infectious bovine rhinotracheitis, Bluetongue, Chlamydia and Brucella antibodies in dairy animals. Indian $J$ Comp Microbiol Immunol Infect Dis 7:139-143.

Tresamol, P. V., Rincy, K. M., \& Dev, P. A. (2019). Seroprevalence of Bovine Herpes Virus-1 among Cattle and Buffaloes in Central Kerala, India. International Journal of Livestock Research, 1(10), 68-73. doi: 10.5455/ijlr.20190611095243.

Tripathi D, Sharma NC, Singh SK, Gupta K, Lavleen. 1998. Detection of Seropositivity for Bovine Herpes Virus-1 in repeat breeder crossbred cattle. Indian Vet. Med. J. 22: 45-46.

Vaid J, Lalkrishna, Kaushal RS. (1991). Seroprevalence of animal diseases in Himachal Pradesh. Indian Vet. J., 68: 705-707.

\section{How to cite this article:}

Sheza Farooq, Aman Kumar, Suman Chaudhary and Sushila Maan. 2019. Bovine Herpesvirus 1 (BoHV-1) in Cattle and Buffalo: A Review with Emphasis on Seroprevalence in India. Int.J.Curr.Microbiol.App.Sci. 8(12): 28-35. doi: https://doi.org/10.20546/ijcmas.2019.812.005 